\title{
АГРОПРОМЫШЛЕННОСТЬ
}

УДК 631.362.36:57.087.3

https://doi.org/10.47533/2020.1606-146X.26

A. B. OSPANOV, B. O. ${ }^{*}$ KULZHANOVA, SH. D. TOLYBAYEV

Kazakh Research Institute of Processing and Food Industry, Almaty, Kazakhstan

\section{RESEARCH OF DESIGN AND TECHNOLOGICAL PARAMETERS OF CLEANING CLOVER SEEDS BY COLOR SORTING}

The article presents the results of study to establish the design and technological parameters of an experimental sample of the color sorter, carried out within the framework of the grant project of the Ministry of Education and Science of the Republic of Kazakhstan AP05130398. The regularities of the technological process of color sorting - cleaning of clover seeds from seeds of quarantine and hardseparable impurities and rational regimes providing high efficiency of processing of clover seed material - have been established. A constructive feature of the tray feeding the seed mixture is proposed, which allows reducing the massiveness of the separator while increasing the productivity, reducing the useful production area.

Key words: cleaning seeds of fodder crops (clover) from quarantine and hard-separable impurities, color sorting.

Introduction. The quality of succulent feed for animal husbandry is determined by the availability of full seeds, which in turn is determined by the level of equipment of seed farms with effective seed-cleaning unit for cleaning seed material from seeds of quarantine and hard-separable weeds. Today, seed producers of fodder crops in the country are importdependent for clover seeds, about $60 \%$ of seed material is purchased abroad [1].

In world practice, the highest results of cleaning seeds of quarantine and hard-separable impurities are achieved by separating machines, the operating principle of which is based on opticalelectronic recognition of seeds of impurities. More than 15 machine manufacturing companies produce these color sorting machines in the world [2]. Their cost varies from 15 to 120 thousand US dollars, which is unbearable for small producers of fodder crops in the country.

As part of our project, we have set a goal - to improve the design and technological parameters of the color sorter, achieving a reduction in its cost.

Research methodology and results. Researches were carried out on an experimental sample of the color sorter [3], the block diagram of which is shown in Figure 1. The sequence of technological processes in the color sorter includes: SH - storage hopper; VT vibrating tray; IPT - inclined pitched tray; VC - video cameras; RU - recognition unit; MC - microcontroller; PE - pneumatic ejectors; SA1; SA2 - respectively, amplifiers for signals 
of pneumatic ejectors and vibrating tray; Ifr. and IIfr. - respectively, outlet pipes for the first (alfalfa seeds) and second (seeds of quarantine and hard-separable impurities) fractions.

The experimental setup is equipped with CCD Nikon AF NIKKOR cameras $(52 \mathrm{~mm})$ with a minimum resolution of 1800-4500 pixels. A Raspberry Pi3 processor was used as a microcontroller, and a JMGD LED-W LED lamp was used to supply lighting, providing $321 \mathrm{x}$ illumination in the object recognition area. Also, the color sorter is equipped with a Vibrator110V Small modei vibrating tray, Ejector 20 Blocks pneumatic ejectors, a Trays size $306 \mathrm{~mm}$ profile pitched tray, a 64 Holes nozzle plate blowing panel, an air filter and a valve.

The optical-electronic control unit operates on the basis of its own software product "Digital Seed Cleaning", which makes it possible to recognize seeds of quarantine and hardseparable impurities with defects of up to 64 classes [4]. The performance of the separator was regulated by the speed of transportation on a horizontal vibrating tray, at which uniform movement of the flow of seeds was ensured in one layer. Once in the survey area, each seed is examined by cameras separately, so that a high degree of purity of the seed fraction of the main crop can be achieved with a color sorter.

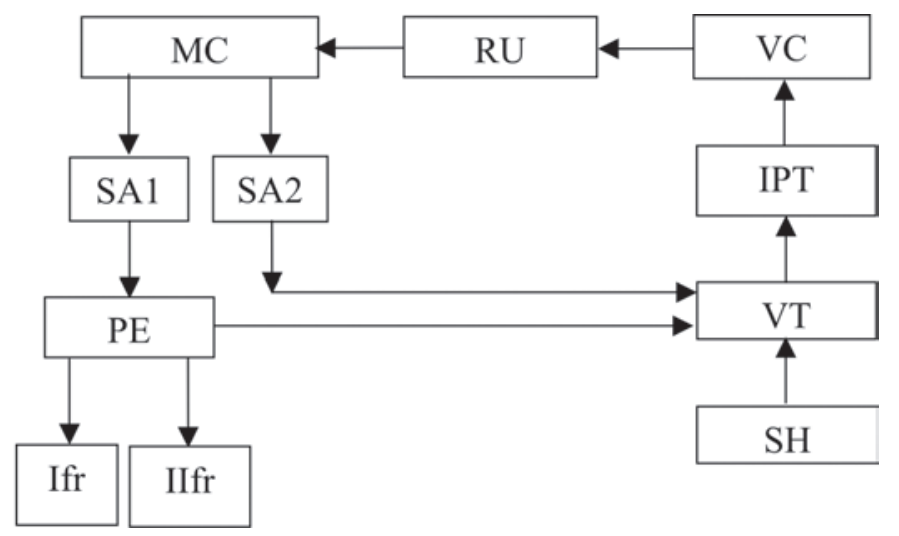

Figure 1 - Block diagram of technological processes in the color separator

Basically, impurity seeds differ from clover seeds in shape, weight and color. But, there is a certain amount of impurities $(0.2-1.5 \%)$ that have identical parameters with clover seeds. Because of this, clover seeds overlap with impurities in the inspection area, which leads to loss - carryover of full alfalfa seeds to waste, or to an increase in waste in a suitable product, and this, in turn, affects the performance of the separator as a whole.

Based on the above, the following adjustable parameters of the cleaning process are adopted, which determine the outcome of the technological process of optical-electronic separation: the productivity of the vibrating horizontal tray; angle of inclination and length of the pitched tray; place of installation of pneumatic ejectors. Decoding of the video frames made it possible to determine the speed of vibratory transport of the mixture in the range from 0.85 to $2.5 \mathrm{~m} / \mathrm{s}$, at a frequency of $150 \ldots 3501 / \mathrm{min}$ and amplitude of oscillations of $0.5 \mathrm{~mm}$. In all experiments, the moisture content of the seed mixture varied within $14.0 \% \ldots$ 
$15.0 \%$. In the experimental seed mixture, the content of impurities was: quarantine $-0.09 \%$; hard-separable $-0.17 \%$.

The quantitative and qualitative analysis of the technological process of cleaning clover seed from quarantine and hard-separable impurities was assessed by two indicators:

- the coefficient of purity $\varepsilon$ of clover seeds, which evaluates the quality aspect of the separation process, is equal to the ratio of the mass of clover seeds in the first fraction $M_{1 C}$ to the total mass of the first fraction, $\varepsilon=\frac{M_{1 C}}{M_{1}} \cdot 100 \%$;

- the coefficient of clover seed carryover $\beta$, reflecting the quantitative aspect of the separation process, is equal to the ratio of the mass of the kernel in the second fraction $M_{2 C}$ to the mass of clover seeds in the original seed mixture $M_{C}, \beta=\frac{M_{2 c}}{M_{C}} \cdot 100 \%$.

The uniformity of feeding the seed mixture in one layer was controlled by a high-speed video camera, and as a result, the dependence of the change in the throughput of the tray $Q$ on its inclination angle $\alpha$, at various values of the tray length $L$.

As can be seen from the dependence $Q(\alpha)$ (Fig. 2), with an increase in the angle of inclination of the pitched tray, it is possible to achieve an increase in the throughput of the chute, i.e. improve productivity. At the same time, with an increase in the angle of inclination of the tray, the value of productivity approaches the extreme, and with values of $\alpha$ close to 90 degrees productivity becomes the same for all cases of tray length $L$, which is quite natural that when, upon reaching the vertical position of the tray, in all cases of tray length, the speed of movement of the seeds is equal to the speed of free fall.

The design productivity of the machine sample $-500 \mathrm{~kg} / \mathrm{h}$ is ensured with the length and inclination angle of the tray equal, respectively, $L\left(y_{1}\right)=30 \mathrm{~cm}-\alpha=60^{\circ} \ldots 65^{\circ} ; L\left(y_{2}\right)=$ $=50 \mathrm{~cm}-\alpha=55^{0} \ldots 60^{\circ} ; L\left(y_{3}\right)=70 \mathrm{~cm}-\alpha=53^{0} \ldots 55^{\circ}$.

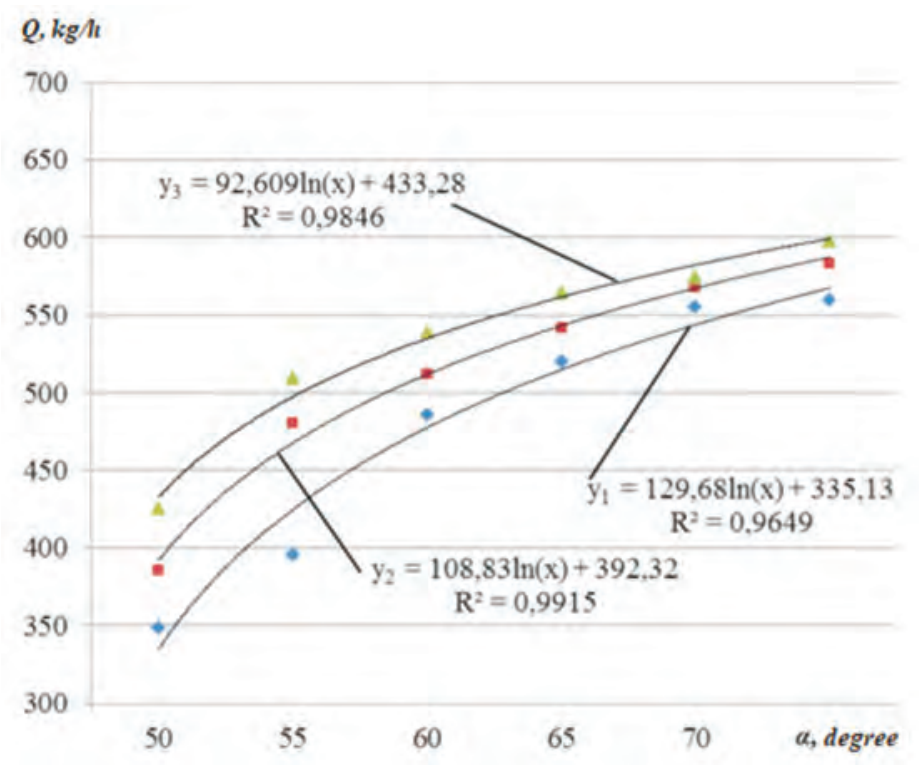

Figure 2 - Dependence $\mathrm{Q}(\alpha)$ 
Figure 3 shows the dependence of the coefficient of purity of the seed mixture of clover $\varepsilon$ when cleaning from hard-separable impurities (seeds of the cornflower and pigweed) from the angle of inclination of the tray $\alpha$, under experimental conditions: productivity - 500 $\mathrm{kg} / \mathrm{h}$; tray width - $120 \mathrm{~mm}$; the surface of the tray - smooth glass.

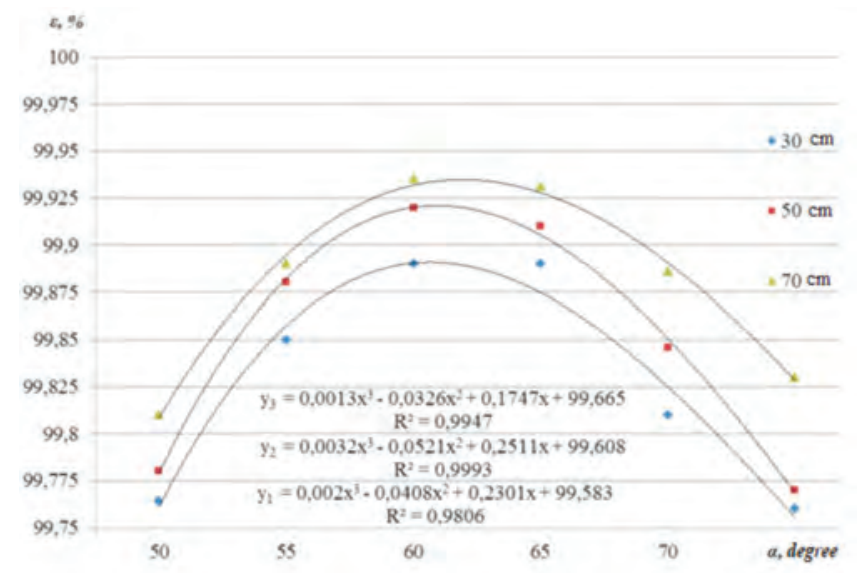

Figure 3 - Dependence $\varepsilon(\alpha)$ during cleaning hard-separable impurities

As it can be seen, the dependence $\varepsilon(\alpha)$ is extreme in nature - it reaches a maximum with an increase in the angle of inclination of the pitched tray and then decreases, the highest values of alfalfa purity correspond to a longer tray $-70 \mathrm{~cm}$, with an angle of inclination of the pitched tray $-58^{0} \ldots 65^{0}$. This is due to the fact that at small angles of inclination of the tray, the purity of the seeds decreases, due to an increase in the flow of the mixture, which complicates the conditions for recognizing objects, and at large angles of inclination of the tray, the number of seeds bouncing off the tray increases, which violates the uniformity of distribution of seeds along the width and length of the tray ...

Figure 4 shows the dependence $\varepsilon(\alpha)$ when cleaning from quarantine impurities (seeds of pink bitterling and dodder), under the conditions: productivity - $500 \mathrm{~kg} / \mathrm{h}$; the distance between the tray and the center of the ejector nozzle is $90 \mathrm{~mm}$.

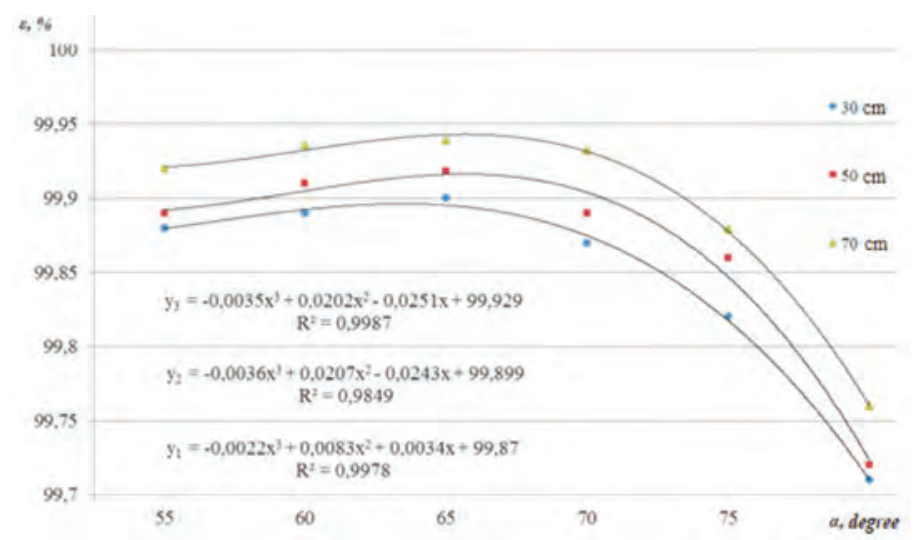

Figure 4 - Dependence $\varepsilon(\alpha)$ during cleaning quarantine impurities 
As it can be seen, at an angle of inclination of the tray within $60^{\circ} \ldots 65^{\circ}$, the greatest degree of clover seeds cleaning from quarantine impurities is provided. Moreover, this is observed in all values of the tray length.

Figure 5 shows the dependence $\beta(\alpha)$, under the conditions: productivity $-500 \mathrm{~kg} / \mathrm{h}$; the distance between the tray and the ejector is $90 \mathrm{~mm}$. As can be seen, the $\beta(\alpha)$ dependence has a negative extreme character with a low value of clover seed carryover to waste. With the values of the inclination angle of the tray from $62^{\circ}$ to $66^{\circ}$, the carryover of clover seeds to waste is below $2 \%$, which meets the requirements for organizing the production of fodder seeds.

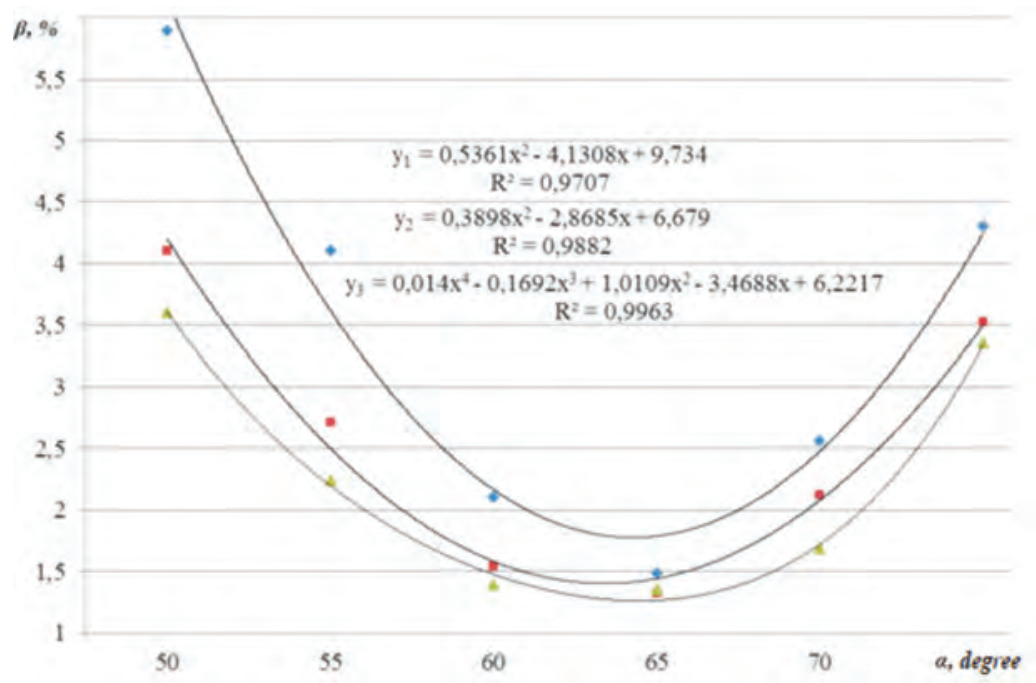

Figure 5 - Dependence $\beta(\alpha)$

Based on the results of the research, it is concluded that rational design and technological parameters of the experimental sample of the color sorter have been determined, which ensure the quality of clover seed material that meets the requirements for the production of fodder seeds. With a pitched tray width of $120 \mathrm{~mm}$, uniform feed of the seed mixture in one layer was achieved at a productivity of $500 \mathrm{k} / \mathrm{h}$. The highest purity of clover seeds from quarantine and hard-separable impurities $(99.8 \%)$ and clover seeds carry-over to waste (less than $2 \%$ ) was reached at an angle of inclination of the pitched tray of $60^{\circ} \ldots 65^{\circ}$.

In general, the insignificant influence of the tray length (in the range from $30 \mathrm{~cm}$ to 70 $\mathrm{cm}$ ) on the techno-design parameters of the cleaning process was established, which makes it possible to assert the possibility of reducing the tray length to $30 \mathrm{~cm}$, while at the same time achieving sufficiently high cleaning rates for the clover seed mixture.

\section{REFERENCES}

1 State program for the development of the agro-industrial complex of the Republic of Kazakhstan for 2017-2021. Astana, February 14, 2017.

2 Analytical report DISCOVERY RESEARCH GROUP. Analysis of the color sorters market in Russia. https://drgroup.ru/components/com_jshopping/files/demo_products/Demo.Analizrynkafotoseparatorov-v-Rossii.pdf (19.07.2020). 
3 A.B. Ospanov, B.O. Toxanbayeva, Sh.D. Tolybayev, D.Sh. Baimuratov, N. Omarov. Research of technological parameters of an optical-electronic separator / Scientific and practical electronic journal “Original Research” (ORIS). V. 9, № 10. - 2019. - P. 96-102.

4 Ospanov, A.B., Toxanbayeva, B.O., Tolybayev, Sh.Zh. "Digital seed Cleaning" program. Certificate of entering information into the state register of rights to objects protected by copyright No. 11519 dated August 4, 2020. Object creation date: 07/27/2020

\title{
А. Б.ОСПАНОВ, Б. О. ҚҰЛЖАНОВА, Ш. Д. ТОЛЫБАЕВ
}

Қазақ құайта өңудеу және тавам өнеркәсіптері выльмии-зерттеу институты, Алматы к̧аласы

\section{ФОТОСҰРЫПТАУ МЕН БЕДЕ ТҰҚЫМДАРЫН ТАЗАЛАУДЫН КОНСТРУКТИВТІК-ТЕХНОЛОГИЯЛЫК ПАРАМЕТРЛЕРІН ЗЕРТТЕУ}

\begin{abstract}
Мақалада ҚР БжҒМгранттық қаржыландырылван АР05130398жобасы аясында жүргізілген фотосепаратордың тәжірибелік үлгісінің тиімді конструктивтік-технологиялық параметрлерін анықтауга бавытталван зерттеу нәтижелері келтірілген. Фотосұрыптау технологиялық проиесінің жоварвы тиімділікті көрсеткіштеріне жеткізетін заңдыльқтары айқындалды - беде тұқыммдарын карантинді және құиын бөлінетін қзоспалардар тазарту мен рационалды режимдерін анықталды. Тұқылмдық құспаны көлбеу бавыттаушының сепаратордың массивті көлемін азайтуга мүмкіндік беретін конструктивті тиімді сұлбасы ұсынылды, ол өзгешелік өндірістік ауданды кішірейте отырып, өнімділікті көбейтуге мүмкіндік береді.

Түйін сөздер: мал азывы дақыллдарының тұқыымдарын (беде) карантиндік және құиын бөлінетін қоспалардан тазарту, фотосұрыптау.
\end{abstract}

\section{А. Б. ОСПАНОВ, Б. О. КУЛЖАНОВА, Ш. Д. ТОЛЫБАЕВ}

Казахский научно-исследовательский институт перерабатывающей и пищевой промышленности, г. Алматы

\section{ИССЛЕДОВАНИЕ КОНСТРУКТИВНО-ТЕХНОЛОГИЧЕСКИХ ПАРАМЕТРОВ ОЧИСТКИ СЕМЯН КЛЕВЕРА ФОТОСЕПАРИРОВАНИЕМ}

Представлены результаты исследования по определению конструктивно-технологических параметров экспериментального образиа фотосепаратора, проводимые в рамках грантового проекта МОН РК АР05130398. Установлены закономерности технологического проиесса фотосепарирования - очистки семян клевера от семян карантинных и трудноотделимых примесей и рациональные режимы, обеспечивающие высокие показатели эффективности обработки семенного материала клевера. Предложена конструктивная особенность подающего семенную смесь лотка, позволяющую уменьшить массивность сепаратора при увеличении производительности, снижая полезную производственную площадь.

Ключевые слова: очистка семян кормовых культур (клевера) от карантинных и трудноотделимых примесей, фотосепарирование. 